\title{
CORRESPONDENCE
}

\section{MOINIAN PALAEOCURRENT DIRECTIONS AT FARAID HEAD, SUTHERLAND}

SIR,-During the course of research on the Torridonian sediments of extreme north-west Scotland, the writer obtained some palaeocurrent data from the Moinian rocks at Faraid Head on the north coast of Sutherland.

The rocks at Faraid Head probably were once well-laminated, mediumgrained felspathic sandstones containing occasional beds of silty mudstone and rare gritty bands. Disturbed bedding and cross-stratification occur sporadically throughout the psammitic rocks. Cross-stratification is predominantly of the planar type, with subordinate isolated trough cross-stratification and ripple-drift cross-lamination. Individual cross-stratified sets rarely exceed $15 \mathrm{~cm}$ in thickness. The sequence dips eastwards at 25 to 30 degrees, and is not tectonically deformed.

The cross-stratification was studied in three dimensions, a hammer and chisel being used to expose the surfaces of cross-strata. Cross-stratal attitudes were obtained by (1) recording the orientation of cross-strata and contiguous major bedding planes with a Brunton compass, and (2) correcting for tectonic tilt by means of a stereographic net. Such a simple rotation, of course, does not take account of any multiple tilting that the Moinian rocks may have undergone. The following dip directions were obtained at three localities spanning an apparent thickness of about $700 \mathrm{~m}$ (results in whole circle true bearings) :

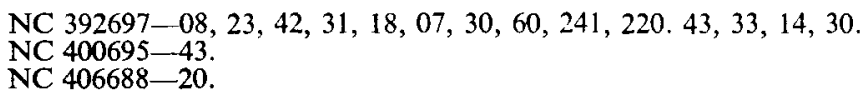

These sixteen directions give a vector mean bearing of 25 degrees, with a vector magnitude of 73 per cent (method of Curray, 1956). Mean dip of cross-strata is 17 degrees. A rose diagram of the dip directions and a histogram of dip magnitude are shown in Text-fig. 1.

Although planar cross-stratification is dominant, none of the sets contain internal structures suggesting that the cross-strata built out at wide angles to local palaeocurrent directions (see Williams, 1966b). Hence, the vector mean of 25 degrees probably is a fair estimate of Moinian palaeocurrent directions at Faraid Head.

This mean palaeocurrent direction is in accord with the findings of Soper (1960) some $110 \mathrm{~km}$ to the south, and the more general observations of Wilson et al. (1953), who showed that over a wide area and through a great thickness the palaeocurrent directions in the Moinian have a strong northerly component. Clearly, more detailed observations are needed. However, even at this early stage, it appears quite likely that the general movement of Moinian currents was towards the north-east sector. It is noteworthy that such a direction would parallel the proposed lines of facies variation in the Torridonian (Williams, 1966a, Fig. 3). What does this mean in terms of Torridonian-Moinian correlation? The time is ripe for an all-out sedimentological attack on the Moinian.

\section{REFERENCES}

Curray, J. R., 1956. The analysis of two-dimensional orientation data. J. Geol., 64, 117-131.

SOPER, N. J., 1960. A note on current-bedded Moines near Garve, Wester Ross. Geol. Mag., 97, 504-508. 


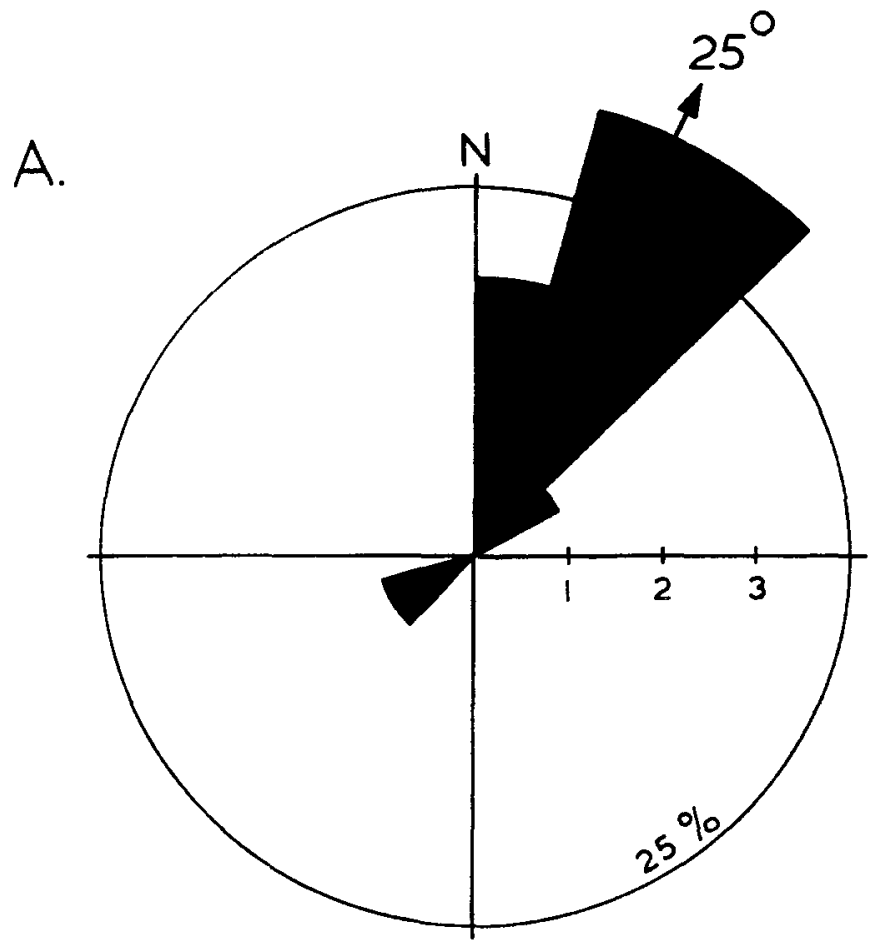

B.

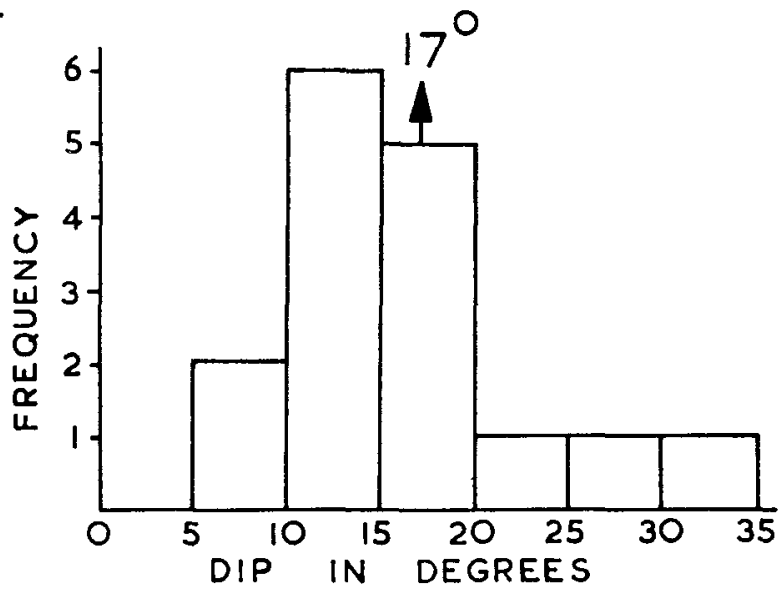

TEXT-FIG. 1.-A. Rose diagram of palaeocurrent directions determined from the Moinian metasediments at Faraid Head, Sutherland. Number of measurements $=16$; vector mean bearing $=25$ degrees ; vector magnitude $=73$ per cent. B. Histogram of 16 cross-stratal inclinations, Faraid Head. Mean inclination $=17$ degrees. Cross-stratified sets measured ranged from $2 \cdot 5$ to $37 \mathrm{~cm}$ in thickness, averaging $12 \mathrm{~cm}$. 
Williams, G. E., 1966a. Palaeogeography of the Torridonian Applecross Group. Nature, Lond., 209, 1303-1306.

1966b. Planar cross-stratification formed by the lateral migration of shallow streams. J, sedim. Petrol., 36, 742-746.

Wilson, G., J. Watson, and J. Sutron, 1953. Current bedding in the Moine Series of north-western Scotland. Geol. Mag., 90, 377-387.

\author{
DEPARTMENT OF GEOLOGY, \\ UNIVERSITY OF ADELAIDE, \\ South Australia. \\ 10th April, 1967.
}

G. E. Williams.

\title{
GEOPHYSICAL INVESTIGATIONS ON THE BOUNDARIES OF THE MOUNTSORREL GRANITE
}

Sir,-We would like to comment on some points raised in the paper by D. Davies and D. H. Matthews (Geol. Mag. 103 (6), 534-547, 1966). The authors state that "Spink and Strauss (1965), on the evidence of the regional gravity gradient... postulated that a fault runs somewhat as shown in Text-fig. 1 ". However, the gravity gradient referred to by us (1965) is not regional, but is a local gradient of about 6.7 milligals per mile over a distance of 1.2 miles. The regional gradient to the east of this steep zone, from about 1 mile S.E. of Loughborough to the vicinity of Widmerpool, is about 1.5 milligals per mile over a distance of 6.8 miles. The local gradient across the postulated Loughborough Fault is thus over four times as great as the regional gradient to the N.E. The gradient across such significant faults as the Boothorpe Fault, which separates the Leicestershire and South Derbyshire Coalfields, is about 4.1 milligals per mile over about 1.2 miles at a point where the throw is known to be about 1,500 feet. The steep gradient in the vicinity of Loughborough cannot thus be lightly dismissed. We have also suggested (1965) that faults similar to, but opposite in throw to the Thringstone Fault (which lies along the eastern boundary of the Leicestershire Coalfield) may be present to the N.E. of Charnwood Forest, from structural considerations.

Falcon and Tarrant (1951), on the basis of the regional gravity pattern, suggested the presence of an Upper Carboniferous basin across the area of the gravity low centred upon Stanton on the Wolds, and this agrees with some geological evidence available from boreholes near Wysall and Widmerpool (Spink and Strauss, 1965, p. 584). It is generally agreed that Carboniferous Limestone is present below the Upper Carboniferous, and the Geological Survey (1956) use a specific gravity of 2.65 for the Carboniferous Limestone as against 2.7 for Charnian rocks and the Mountsorrel intrusion. With such small differences in density there is no need to assume the presence of "... relatively dense Charnian and igneous rocks (directly) beneath the Triassic and Jurassic rocks of the Soar Valley". The authors do not indicate the manner in which regional gradient has been corrected; if this gradient is in fact the steep gradient to which we have referred, its removal would presumably cancel the effect of the Loughborough Fault. In that case the remaining vertical "step" down shown by the authors' survey, may well be a minor fault as referred to in their paper, but could also represent an erosion feature or a fault scarp, and is not necessarily related to the Loughborough Fault. Minor faulting can be seen in the quarry at Mountsorrel. There is evidence that some projecting rock masses in the Midlands, such as at Breedon, are not affected by Triassic faulting (Kent, Joysey, and Taylor, in Spink and Strauss, 1964, Ford (personal communication), and Spink (1965). In the case of the 